\title{
Author Correction: Phage-assisted evolution of an adenine base editor with improved Cas domain compatibility and activity
}

Michelle F. Richter, Kevin T. Zhao (D), Elliot Eton (D), Audrone Lapinaite (D), Gregory A. Newby (D), Benjamin W. Thuronyi, Christopher Wilson (D), Luke W. Koblan, Jing Zeng, Daniel E. Bauer, Jennifer A. Doudna (D) and David R. Liu (D)

Correction to: Nature Biotechnology https://doi.org/10.1038/s41587-020-0453-z, published online 16 March 2020.

In the version of this article initially published online, the edited bases at site 18 in Fig. 2e were labeled A6 and A8; they are A9 and A11, respectively. In Supplementary Fig. 6, the $x$-axis labels for site 18 read, from left to right, A2, A3, A4, A6, A8, A16, A17, A19 and A20; the correct labels are A5, A6, A7, A9, A11, A19, A20, A22 and A23. The errors have been corrected in the print, PDF and HTML versions of the article.

Published online: 20 May 2020

https://doi.org/10.1038/s41587-020-0562-8

(c) The Author(s), under exclusive licence to Springer Nature America, Inc. 2020

\section{Publisher Correction: Base editors for simultaneous introduction of C-to-T and A-to-G mutations}

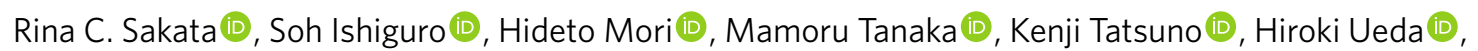

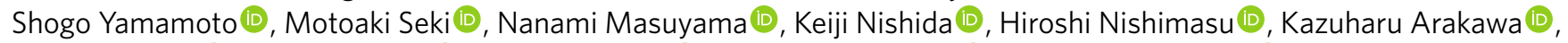
Akihiko Kondo (1D, Osamu Nureki (1D, Masaru Tomita (D), Hiroyuki Aburatani (iD) and Nozomu Yachie (ID)

Correction to: Nature Biotechnology https://doi.org/10.1038/s41587-020-0509-0, published online 2 June 2020.

In the version of this article initially published online, the date published was given as 01 June 2020 . The correct date is 02 June 2020 . The error has been corrected in the print, PDF and HTML versions of the article.

Published online: 5 June 2020

https://doi.org/10.1038/s41587-020-0585-1

(c) The Author(s), under exclusive licence to Springer Nature America, Inc. 2020

\section{Publisher Correction: Engineered CRISPR-Cas12a variants with increased activities and improved targeting ranges for gene, epigenetic and base editing}

Benjamin P. Kleinstiver (D), Alexander A. Sousa, Russell T. Walton, Y. Esther Tak, Jonathan Y. Hsu, Kendell Clement, Moira M. Welch, Joy E. Horng (D), Jose Malagon-Lopez, Irene Scarfò (D, Marcela V. Maus (D), Luca Pinello,

Martin J. Aryee (D) and J. Keith Joung

Correction to: Nature Biotechnology https://doi.org/10.1038/s41587-018-0011-0, published online 11 February 2019.

In the HTML version of this article initially published, Benjamin P. Kleinstiver was not listed as a corresponding author.

Published online: 15 June 2020

https://doi.org/10.1038/s41587-020-0587-z

(c) The Author(s), under exclusive licence to Springer Nature America, Inc. 2020 